\title{
TINGKAT BIOKONSENTRASI LOGAM BERAT DAN GAMBARAN HISTOPATOLOGI IKAN MUJAIR (Oreochromis Mossambicus) YANG HIDUP DI PERAIRAN TUKAD BADUNG KOTA DENPASAR
}

\author{
Made Rahayu Kusumadewi ${ }^{1 *}$, I Wayan Budiarsa Suyasa ${ }^{2}$, I Ketut Berata ${ }^{3}$ \\ ${ }^{1}$ Program Studi Magister Ilmu Lingkungan Universitas Udayana Bali \\ ${ }^{2}$ Program Studi Magister Ilmu Lingkungan Universitas Udayana Bali \\ ${ }^{3}$ Fakultas Kedokteran Hewan Universitas Udayana Bali \\ *Email:kusumadewirahayu@gmail.com
}

\begin{abstract}
Tukad Badung River is one of the potential contamination of heavy metal sare very highin the city of Denpasar. Tilapia (Oreochromis mossambicus) isa commonspecies of fish found in the river and became the object of fishing by the public. The fish is usually consume das a food ingredient forever yangler. Fish can be used as bio-indicators of chemical contamination in the aquatic environment. Determination of heavy metal bioconcentration and analysis of liver histopathology gills organs and muscles is performed to determine the content of heavy metals $\mathrm{Pb}, \mathrm{Cd}$, and $\mathrm{Cr}^{+6}$, and the influence of heavy metal exposure to changes in organ histopathology Tilapia that live in Tukad Badung.

In this observational study examined the levels of heavy metal contamination include $\mathrm{Pb}, \mathrm{Cd}_{\text {and }} \mathrm{Cr}^{+6}$ in Tilapia meat with AAS method (Atomic Absorption Spectrofotometric), and observe the histopathological changes in organ preparations gills, liver, and muscle were stained with HE staining (hematoxylin eosin).

Low $\mathrm{Pb}$ content of the fish that live in Tukad Badung $0.8385 \mathrm{mg} / \mathrm{kg}$ and high of $20.2600 \mathrm{mg} / \mathrm{kg}$. The content of heavy metals $\mathrm{Pb}$ is above the quality standards specified in ISO $7378: 2009$ in the amount of 0.3 $\mathrm{mg} / \mathrm{kg}$. The content of $\mathrm{Cr}^{+6}$ low of $1.1402 \mathrm{mg} / \mathrm{kg}$ and the highest $\mathrm{Cr}^{+6}$ is $6.2214 \mathrm{mg} / \mathrm{kg}$. The content of $\mathrm{Cr}^{+6}$ is above the quality standards established in the FAO Fish Circular 764 is equal to $1.0 \mathrm{mg} / \mathrm{kg}$. In fish with $\mathrm{Pb}$ bioconcentration of $0.8385 \mathrm{mg} / \mathrm{kg}$ and $\mathrm{Cr}^{+6}$ of $1.1402 \mathrm{mg} / \mathrm{kg}$ was found that histopathological changes gill hyperplasia and fusion, the liver was found degeneration, necrosis, and fibrosis, and in muscle atrophy found. Histopathologicalchangessuch asedema and necrosis ofthe liveris foundin fishwith $\mathrm{Pb}$ bioconcentration of $4.5225 \mathrm{mg} / \mathrm{kg}$ and $\mathrm{Cr}^{+6}$ amounted to $2.5163 \mathrm{mg} / \mathrm{kg}$.

Bio concentration of heavy metal contamination of lead $(\mathrm{Pb})$ and hexavalent chromium $\left(\mathrm{Cr}^{+6}\right)$ on Tilapia ( Oreochromis mossambicus ) who lives in Tukad Badung river waters exceed the applicable standard. Histopathological changes occur in organs gills, liver, and muscle as a result of exposure to heavy metals lead and hexavalent chromium. Advised the people not to eat Tilapia that live in Tukad Badung.
\end{abstract}

Keywords : Bioconcentration, heavy metals, Tilapia

\section{PENDAHULUAN}

Sungai memiliki fungsi beragam diantaranya sumber air minum, mandi, mencuci dan rekreasi atau memancing. Di kota Denpasar terdapat sebuah sungai yang umum dimanfaatkan oleh masyarakat untuk lokasi memancing yaitu Tukad Badung. Ikan Mujair merupakan ikan yang banyak diperoleh para pemancing ikan di Tukad Badung, umumnya ikan mujair yang diperoleh untuk dikonsumsi. Penurunan kualitas air mengakibatkan rendahnya kualitas hidup dari ikan yang hidup di dalamnya. Sumber limbah yang berpotensi mencemari Tukad Badung adalah limbah industri (industri pengolahan dan industri pencelupan), limbah rumah tangga, limbah bengkel, limbah limpasan jalan, limbah peternakan, limbah rumah sakit, limbah pasar dan sebagainya. Logam berat merupakan istilah yang digunakan untuk menamai kelompok metal dan metalloid dengan densitas lebih besar dari $6 \mathrm{~g} / \mathrm{cm}^{3}$ diantaranya timbal $(\mathrm{Pb})$, kadmium $(\mathrm{Cd})$, dan kromium heksavalen $\left(\mathrm{Cr}^{+6}\right)$. Menurut Bryan (1976) dalam Purnomo (2008), logam berat yang masuk ke dalam perairan akan dipindahkan dari badan air melalui tiga proses yaitu pengendapan, adsorbsi, dan absorbsi oleh organismeorganisme perairan. Menurut Mason (2002), tingginya tingkat cemaran di perairan akan mempengaruhi keadaan fisiologis ikan yang disertai kerusakan anatomi. Menurut Geonarso (1988) dalam Cahaya (2009) ikan merupakan salah satu organisme yang dapat digunakan dalam uji untuk mengetahui efek beracun dari beberapa cemaran bahan kimia dalam suatu lingkungan perairan. Analisa histopatologi dapat digunakan untuk mengetahui gambaran kesehatan ikan melalui perubahan struktur yang terjadi pada organ yang menjadi target utama dari bahan pencemar seperti insang, hati, dan daging (Dutta, 1996). Berdasarkan permasalahan di 
atas, maka dilakukan penelitian untuk menentukan tingkat biokonsentrasi pencemaran logam berat dan gambaran histopatologi ikan Mujair (Oreochromis mossambicus) yang hidup di perairan Tukad Badung Kota Denpasar.

\section{METODE}

\subsection{Penentuan konsentrasi logam berat timbal (Pb), kadmium (Cd) dan kromium heksavalen $\left(\mathrm{Cr}^{+6}\right)$ pada daging ikan}

Sampel daging di haluskan dengan cara diblender hingga homogen. Sampel daging diambil sebanyak 10 gram pada tiap ikan. Dilakukan pengujian kandungan logam berat pada sampel ikan dengan metode AAS (Atomic Absorption Spectrofotometric). Sampel dibagi menjadi dua bagian, 5 gram untuk kontrol positif dan 5 gram untuk sampel. Ditambahkan 0,25 ml larutan standar $1 \mathrm{mg} / \mathrm{l}$ ke dalam sampel untuk membuat spiked atau kontrol positif. Spiked diuapkan diatas hot plate pada suhu $100^{\circ} \mathrm{C}$ sampai kering. Sampel dan spiked dimasukkan kedalam tungku pengabuan dan tutup separuh permukaannya. Suhu tungku pengabuan dinaikkan secara bertahap $100^{\circ} \mathrm{C}$ setiap 30 menit hingga mencapai $450^{\circ} \mathrm{C}$ dan dipertahankan selama 18 jam. Sampel dan spiked dikeluarkan dari tungku pengabuan dan dinginkan pada suhu kamar. Setelah dingin ditambahkan $1 \mathrm{ml}$ HNO3 65\%, digoyangkan secara hati-hati sehingga semua abu terlarut dalam asam dan selanjutnya diuapkan diatas hot plate pada suhu $100^{\circ} \mathrm{C}$ sampai kering. Setelah kering sampel dan spiked dimasukkan kembali ke dalam tungku pengabuan. Suhu dinaikkan secara bertahap $100^{\circ} \mathrm{C}$ setiap 30 menit hingga mencapai $450^{\circ} \mathrm{C}$ dan dipertahankan selama 3 jam. Setelah abu terbentuk sempurna berwarna putih, sampel dan spiked didinginkan pada suhu ruang. Ditambahkan $5 \mathrm{ml}$ $\mathrm{HCl} 6 \mathrm{M}$ kedalam masing-masing sampel dan spiked digoyangan secara hati-hati sehingga semua abu larut dalam asam. Diuapkan diatas hot plate pada suhu $100^{\circ} \mathrm{C}$ sampai kering. Ditambahkan $10 \mathrm{ml}$ HNO3 0,1 M dan didinginkan pada suhu ruang selama 1 jam, larutan dipindah kedalam labu takar polyproylene $50 \mathrm{ml}$ dan ditambahkan larutan matrik modifier, tepatkan sampai tanda batas dengan menggunakan HNO3 0,1 M. Larutan standar kerja $\mathrm{Cd}, \mathrm{Pb}$ dan $\mathrm{Cr}^{+6}$ disiapkan masing-masing minimal lima titik konsentrasi. Larutan standar kerja, sampel, dan spiked dibaca pada alat spektrofotometer serapan atom graphite fumace pada panjang gelombang 228,8 nm untuk logam $\mathrm{Cd}, 288,3 \mathrm{~nm}$ untuk logam $\mathrm{Pb}$ dan 357,9 untuk logam $\mathrm{Cr}^{+6}$. Konsentrasi $\mathrm{Cd}, \mathrm{Pb}$, dan $\mathrm{Cr}^{+6}$ dalam $\mu \mathrm{g} / \mathrm{g}$ dihitung dengan rumus berikut (SNI 2354.5:2011) :

$$
\text { Konsentrasi }=\frac{(D-E) x F p x V}{W}
$$

Keterangan :

D : konsentrasi sampel $\mu \mathrm{g} / \mathrm{l}$ dari hasil pembacaan AAS

$\mathrm{E}$ : konsentrasi blanko sampel $\mu \mathrm{g} / \mathrm{l}$ dari hasil pembacaan AAS

Fp : faktor pengenceran

$\mathrm{V}$ : volume akhir larutan sampel yang disiapkan (ml), ubah kedalam satuan liter

W : berat sampel (g)

\subsection{Pembuatan preparat histopatologi organ ikan}

Organ insang, hati dan daging diambil. Organ disimpan dalam tissue cassette dan dilakukan fiksasi dalam larutan formalin 10\%.Setelah difiksasi, dilakukan proses dehidrasi dengan satu sesi larutan yang terdiri dari : alkohol 70\%, alkohol 80\%, alkohol 90\%, alkohol 96\%, dan alkohol absolut. Setelah difiksasi, dilakukan proses clearing menggunakan xylol. Sampel diinfiltrasi dengan (blocking) menggunakan alat embedding set lalu dituangkan paraffin cair kemudian dinginkan. Pada blok yang sudah dingin dilakukan sectioning menggunakan microtome dengan ketebalan \pm 4-5 mikron. Preparat di atas gelas objek direndam dalam larutan xylol masing-masing selama 5 menit. Selanjutnya, preparat direndam di dalam alkohol 100\% masingmasing selama 5 menit. Preparat dimasukkan ke dalam aquades dan kemudian direndam dalam Harris Hematoxylin selama 15 menit. Dicelupkan ke dalam aquades dengan cara mengangkat dan menurunkannya. Preparat dicelupkan ke dalam acid alkohol 1\% sebanyak 7-10 kali. Direndam dengan aquades selama 1 menit dan dibilas kembali dengan aquades selama 15 menit dan dimasukkan ke dalam eosin selama 2 menit. Preparat dimasukkan pada seri alkohol bertingkat dari 96\%, 96\%, 100\%, 100\% masing-masing 3 menit hingga ethanol absolute untuk dehidrasi. Preparat dimasukkan pada xylol dua kali selama lima menit dan dikeringkan untuk clearing. Dilakukan mounting media. Preparat histologi diamati dengan pembesaran tertentu di bawah mikroskop dan dicatat perubahan mikroskopik yang ditemukan.

\subsection{Analisa Data}

Data yang diperoleh ditabulasi dan dianalisis secara deskriptif kualitatif serta disajikan dalam bentuk tabel dan grafik. Hasil uji penentuan kandungan logam berat $\mathrm{Pb}$ dan $\mathrm{Cd}$ pada masingmasing lokasi dan tingkat umur dibandingkan dengan baku mutu yang berlaku yaitu SNI 7387:2009 sedangkan untuk logam berat $\mathrm{Cr}^{+6}$ dibandingkan dengan baku mutu pada FAO Fish Circular 764, dan 
ditentukan ikan pada lokasi dan tingkat umur dengan kandungan logam berat paling tinggi hingga terendah. Gambaran histopatologi yang diperoleh dibandingkan dengan histologi normal dari organ insang, hati, dan daging pada masing-masing lokasi dan tingkat umur, sehingga dapat ditentukan ikan pada lokasi dan tingkat umur dengan kerusakan histopatologi organ tertinggi hingga terendah.

\section{HASIL}

Berdasarkan hasil pemeriksaan sampel ikan yang berasal dari Dam Mertagangga didapatkan hasil bahwa kandungan logam berat timbal $(\mathrm{Pb})$ pada ikan Mujair remaja terendah adalah $0,8385 \mathrm{mg} / \mathrm{kg}$ dan tertinggi adalah $2,5550 \mathrm{mg} / \mathrm{kg}$. Sedangkan kandungan logam berat timbal $(\mathrm{Pb})$ pada ikan Mujair dewasa terendah adalah $2,7085 \mathrm{mg} / \mathrm{kg}$ dan tertinggi adalah 3,9027 mg/kg (Tabel 5.1). Untuk kandungan logam berat kromium $\left(\mathrm{Cr}^{+6}\right)$ pada ikan Mujair remaja terendah adalah $1,1402 \mathrm{mg} / \mathrm{kg}$ dan tertinggi adalah $1,3029 \mathrm{mg} / \mathrm{kg}$. Sedangkan kandungan logam berat kromium $\left(\mathrm{Cr}^{+6}\right)$ pada ikan Mujair dewasa terendah adalah 2,3074 mg/kg dan tertinggi adalah 3,2802 mg/ kg (Tabel 1).

Tabel 1. Hasil Pemeriksaan Kandungan Logam Berat $\mathrm{Pb}$ dan $\mathrm{Cr}^{+6}$ pada Ikan Mujair di Dam Mertangangga

\begin{tabular}{lcc}
\hline \multirow{2}{*}{ Sampel } & \multicolumn{2}{c}{ Parameter } \\
\cline { 2 - 3 } & $\mathrm{Pb}(\mathrm{mg} / \mathrm{kg})$ & $\mathrm{Cr}(\mathrm{mg} / \mathrm{kg})$ \\
\hline Ikan Remaja (DM-J01) & 0,8385 & 1,1402 \\
Ikan Remaja (DM-J02) & 0,4986 & 1,2995 \\
Ikan Remaja (DM-J03) & 2,5550 & 1,3029 \\
Ikan Dewasa (DM-A01) & 3,9027 & 2,3074 \\
Ikan Dewasa (DM-A02) & 2,9099 & 2,7931 \\
Ikan Dewasa (DM-A03) & 2,7085 & 3.2802 \\
\hline
\end{tabular}

Kandungan logam berat timbal $(\mathrm{Pb})$ yang terkandung pada ikan Mujair yang diambil pada lokasi kedua yaitu jembatan Gajah Mada diperoleh hasil yaitu kandungan logam berat timbal $(\mathrm{Pb})$ pada ikan Mujair remaja terendah adalah 4,5225 mg/kg dan tertinggi adalah 6,5606 mg/kg. Pada ikan Mujair dewasa kandungan logam berat timbal $(\mathrm{Pb})$ terendah adalah $5,7902 \mathrm{mg} / \mathrm{kg}$ dan tertinggi adalah $6,6225 \mathrm{mg} /$ kg. Sedangkan kandungan logam berat kromium $\left(\mathrm{Cr}^{+6}\right)$ pada ikan Mujair remaja terendah adalah $2,5163 \mathrm{mg} / \mathrm{kg}$ dan tertinggi adalah $3,5141 \mathrm{mg} / \mathrm{kg}$. Sedangkan kandungan logam berat kromium $\left(\mathrm{Cr}^{+6}\right)$ pada ikan Mujair dewasa terendah adalah 3,1363 mg/ $\mathrm{kg}$ dan tertinggi adalah 4,4464 mg/kg (Tabel 2).
Tabel 2. Hasil Pemeriksaan Kandungan Logam Berat $\mathrm{Pb}$ dan $\mathrm{Cr}^{+6}$ pada Ikan Mujair di Jembatan Gajah Mada

\begin{tabular}{lcc}
\hline \multirow{2}{*}{ Sampel } & \multicolumn{2}{c}{ Parameter } \\
\cline { 2 - 3 } & $\mathrm{Pb}(\mathrm{mg} / \mathrm{kg})$ & $\mathrm{Cr}(\mathrm{mg} / \mathrm{kg})$ \\
\hline Ikan Remaja (GM-J01) & 4,5225 & 3,5141 \\
Ikan Remaja (GM-J02) & 5,6950 & 2,7902 \\
Ikan Remaja (GM-J03) & 6,5606 & 2,5163 \\
Ikan Dewasa (GM-A01) & 6,1503 & 3,1363 \\
Ikan Dewasa (GM-A02) & 5,7902 & 4,1056 \\
Ikan Dewasa (GM-A03) & 6,6225 & 4,4464 \\
\hline
\end{tabular}

Pada sampel ikan Mujair yang diambil di Alangkajeng menak diperoleh hasil yaitu kandungan logam berat timbal $(\mathrm{Pb})$ pada ikan Mujair remaja terendah adalah $7,0640 \mathrm{mg} / \mathrm{kg}$ dan tertinggi adalah $8,9524 \mathrm{mg} / \mathrm{kg}$. Kandungan logam berat timbal $(\mathrm{Pb})$ pada ikan Mujair dewasa terendah adalah $8,2428 \mathrm{mg} /$ $\mathrm{kg}$ dan tertinggi adalah $10,6147 \mathrm{mg} / \mathrm{kg}$. Sedangkan kandungan logam berat kromium $\left(\mathrm{Cr}^{+6}\right)$ pada ikan Mujair remaja terendah adalah 4,2919 $\mathrm{mg} / \mathrm{kg}$ dan tertinggi adalah $4,8769 \mathrm{mg} / \mathrm{kg}$. Sedangkan kandungan logam berat kromium $\left(\mathrm{Cr}^{+6}\right)$ pada ikan Mujair dewasa terendah adalah 4,7143 $\mathrm{mg} / \mathrm{kg}$ dan tertinggi adalah 4,9213 $\mathrm{mg} / \mathrm{kg}$ (Tabel 3).

Tabel 3. Hasil Pemeriksaan Kandungan Logam Berat $\mathrm{Pb}$ dan $\mathrm{Cr}^{+6}$ pada Ikan Mujair di Alangkajeng Menak

\begin{tabular}{lcc}
\hline \multirow{2}{*}{ Sampel } & \multicolumn{2}{c}{ Parameter } \\
\cline { 2 - 3 } & $\mathrm{Pb}(\mathrm{mg} / \mathrm{kg})$ & $\mathrm{Cr}(\mathrm{mg} / \mathrm{kg})$ \\
\hline Ikan Remaja (AK-J01) & 7,2554 & 4,8769 \\
Ikan Remaja (AK-J02) & 7,0640 & 4,2919 \\
Ikan Remaja (AK-J03) & 8,9524 & 4,2933 \\
Ikan Dewasa (AK-A01) & 8,2428 & 4,9182 \\
Ikan Dewasa (AK-A02) & 10,6147 & 4,7143 \\
Ikan Dewasa (AK-A03) & 9,9838 & 4,9213 \\
\hline
\end{tabular}

Sampel ikan Mujair remaja yang diambil di Dam Buagan memiliki kandungan logam berat timbal $(\mathrm{Pb})$ terendah adalah 10,3924 $\mathrm{mg} / \mathrm{kg}$ dan tertinggi adalah $11,2952 \mathrm{mg} / \mathrm{kg}$. Pada ikan Mujair dewasa kandungan logam berat timbal $(\mathrm{Pb})$ terendah adalah 13,5833 mg/ $\mathrm{kg}$ dan tertinggi adalah $15,2860 \mathrm{mg} / \mathrm{kg}$. Sedangkan kandungan logam berat kromium $\left(\mathrm{Cr}^{+6}\right)$ pada ikan Mujair remaja terendah adalah 5,2153 $\mathrm{mg} / \mathrm{kg}$ dan tertinggi adalah $5,6165 \mathrm{mg} / \mathrm{kg}$. Sedangkan kandungan logam berat kromium $\left(\mathrm{Cr}^{+6}\right)$ pada ikan Mujair dewasa terendah adalah 5,2696 mg/kg dan tertinggi adalah 5,8388 $\mathrm{mg} / \mathrm{kg}$ (Tabel 4). 
Tabel 4. Hasil Pemeriksaan Kandungan Logam Berat $\mathrm{Pb}$ dan $\mathrm{Cr}^{+6}$ pada Ikan Mujair di Dam Buagan

\begin{tabular}{lcc}
\hline \multirow{2}{*}{ Sampel } & \multicolumn{2}{c}{ Parameter } \\
\cline { 2 - 3 } & $\mathrm{Pb}(\mathrm{mg} / \mathrm{kg})$ & $\mathrm{Cr}(\mathrm{mg} / \mathrm{kg})$ \\
\hline Ikan Remaja (DB-J01) & 10,3924 & 5,2153 \\
Ikan Remaja (DB-J02) & 11,2952 & 5,6165 \\
Ikan Remaja (DB-J03) & 11,1125 & 5,2675 \\
Ikan Dewasa (DB-A01) & 13,5833 & 5,2696 \\
Ikan Dewasa (DB-A02) & 15,2860 & 5,8388 \\
Ikan Dewasa (DB-A03) & 14,1183 & 5,7926 \\
\hline
\end{tabular}

Sedangkan untuk sampel ikan Mujair yang diambil di Dam Estuari mengandung logam berat timbal $(\mathrm{Pb})$ pada ikan Mujair remaja terendah adalah $15,1312 \mathrm{mg} / \mathrm{kg}$ dan tertinggi adalah $16,9638 \mathrm{mg} / \mathrm{kg}$. Pada ikan Mujair dewasa kandungan logam berat $\mathrm{Pb}$ terendah adalah $18,3070 \mathrm{mg} / \mathrm{kg}$ dan tertinggi adalah $20,2600 \mathrm{mg} / \mathrm{kg}$. Sedangkan pada ikan remaja mengandung logam kromium $\left(\mathrm{Cr}^{+6}\right)$ terendah adalah $5,3950 \mathrm{mg} / \mathrm{kg}$ dan tertinggi adalah $5,9382 \mathrm{mg} / \mathrm{kg}$. Pada ikan Mujair dewasa terendah adalah 5,8196 $\mathrm{mg} / \mathrm{kg}$ dan tertinggi adalah 6,2214 mg/kg (Tabel 5).

Tabel 5. Hasil Pemeriksaan Kandungan Logam Berat $\mathrm{Pb}$ dan $\mathrm{Cr}^{+6} \mathrm{pada}$ Ikan Mujair di Dam Estuari

\begin{tabular}{lcc}
\hline \multirow{2}{*}{ Sampel } & \multicolumn{2}{c}{ Parameter } \\
\cline { 2 - 3 } & $\mathrm{Pb}(\mathrm{mg} / \mathrm{kg})$ & $\mathrm{Cr}(\mathrm{mg} / \mathrm{kg})$ \\
\hline Ikan Remaja (DE-J01) & $0,7630^{*}$ & 5,3950 \\
Ikan Remaja (DE-J02) & 15,1312 & 5,4065 \\
Ikan Remaja (DE-J03) & 16,9638 & 5,9382 \\
Ikan Dewasa (DE-A01) & 18,3070 & 5,8196 \\
Ikan Dewasa (DE-A02) & 20,2600 & 6,2214 \\
Ikan Dewasa (DE-A03) & 19,5483 & 6,1254 \\
\hline
\end{tabular}

Keterangan :

* = Merupakan data pencilan. Data diragukan keakuratan akibat kesalahan faktor pemeriksaan maupun faktor-faktor lain.

Berdasarkan hasil pemeriksaan sampel ikan Mujair yang berasal dari 5 (lima) titik lokasi penelitian tidak ditemukan adanya kandungan logam berat kadmium (Cd) pada 2 (dua) kategori umur yaitu remaja dan dewasa.

Pada pembacaan preparat organ insang ikan Mujair yang hidup di Dam Mertagangga diperoleh bahwa semua ikan baik ikan remaja maupun dewasa menunjukkan perubahan histopatologi hiperplasia dan fusi pada organ insang. Perubahan histopatologi organ hati pada ikan remaja berupa degenerasi ditemukan pada 3 ekor ikan, nekrosis pada 3 ekor ikan, dan fibrosis pada 2 ekor ikan dan perubahan histopatologi berupa oedema dan radang tidak ditemukan. Padaikan dewasa ditemukan perubahan histopatologi degenerasi, nekrosis, dan fibrosis pada 3 ikan, sedangkan perubahan histopatologi oedema dan radang tidak ditemukan.Pada organ otot ditemukan perubahan histopatologi yaitu atrofi ditemukan pada semua kategori umur ikan Mujair yang hidup di Dam Mertagangga (Tabel 6).

Tabel 6. Perubahan Histopatologi Hiperplasia dan Fusi pada Organ Insang Ikan Mujair yang Hidup di Dam Mertagangga

\begin{tabular}{lllllllll}
\hline & \multicolumn{1}{c}{ Perubahan Histopatologi } \\
\cline { 2 - 9 } & H & Fu & D & N & Fi & O & R & A \\
\hline Ikan Remaja (DM-J01) & $\sqrt{ }$ & $\sqrt{ }$ & $\sqrt{ }$ & $\sqrt{ }$ & $\sqrt{ }$ & - & - & $\sqrt{ }$ \\
Ikan Remaja (DM-J02) & $\sqrt{ }$ & $\sqrt{ }$ & $\sqrt{ }$ & $\sqrt{ }$ & $\sqrt{ }$ & - & - & $\sqrt{ }$ \\
Ikan Remaja (DM-J03) & $\sqrt{ }$ & $\sqrt{ }$ & $\sqrt{ }$ & $\sqrt{ }$ & $\sqrt{ }$ & - & - & $\sqrt{ }$ \\
Ikan Dewasa (DM-A01) & $\sqrt{ }$ & $\sqrt{ }$ & $\sqrt{ }$ & $\sqrt{ }$ & $\sqrt{ }$ & - & - & $\sqrt{ }$ \\
Ikan Dewasa (DM-A02) & $\sqrt{ }$ & $\sqrt{ }$ & $\sqrt{ }$ & $\sqrt{ }$ & $\sqrt{ }$ & - & - & $\sqrt{ }$ \\
Ikan Dewasa (DM-A03) & $\sqrt{ }$ & $\sqrt{ }$ & $\sqrt{ }$ & $\sqrt{ }$ & $\sqrt{ }$ & - & - & $\sqrt{ }$ \\
\hline
\end{tabular}

\section{Keterangan:}

$\mathrm{H}=$ Hiperplasia $\mathrm{Fu}=$ Fusi $\mathrm{D}=$ Degenerasi $\mathrm{N}=$ Nekrosis

$\mathrm{Fi}=$ Fibrosis $\mathrm{O}=$ Oedema $\mathrm{R}=$ Radang $\mathrm{A}=$ Atropi

Pada ikan Mujair yang hidup di jembatan Gajah Mada ditemukan perubahan histopatologi organ insang berupa hiperplasia dan fusi pada semua kategori umur baik remaja maupun dewasa. Perubahan histopatologi yang terjadi pada organ hati ikan Mujair yang hidup di jembatan Gajah Mada yaitu degenerasi, nekrosis, fibrosis, oedema, dan radang ditemukan pada semua sampel ikan baik ikan dewasa maupun ikan remaja.Perubahan histopatologi atrofi pada otot ditemukan pada keseluruhan sampel ikan Mujair yang hidup di jembatan Gajah Mada baik ikan dewasa maupun remaja (Tabel 7).

Tabel 7. Perubahan Histopatologi Hiperplasia dan Fusi pada Organ Insang Ikan Mujair yang Hidup di Jembatan Gajah Mada

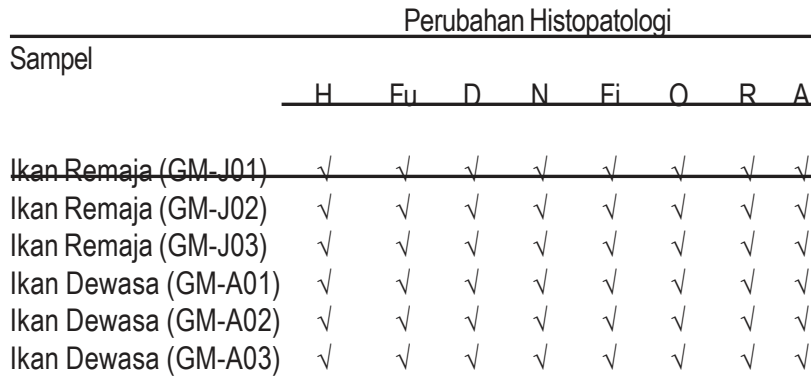

\section{Keterangan}

$\mathrm{H}=$ Hiperplasia Fu = Fusi $\mathrm{D}=$ Degenerasi $\mathrm{N}=$ Nekrosis

$\mathrm{Fi}=$ Fibrosis $\mathrm{O}=$ Oedema $\mathrm{R}=$ Radang $\mathrm{A}=$ Atropi

Pada ikan Mujair yang hidup di Alangkajeng Menak ditemukan perubahan histopatologi pada preparat organ insang berupa hiperplasia dan fusi pada semua kategori umur baik remaja maupun dewasa.Perubahan histopatologi degenerasi, nekrosis, fibrosis, eodema dan radang pada organ hati ditemukan pada semua sampel ikan Mujair baik ikan 
dewasa maupun ikan remaja yang hidup di Alangkajeng Menak.Perubahan histopatologi atrofi pada otot ditemukan pada keseluruhan sampel ikan Mujair yang hidup di Alangkajeng Menak baik ikan dewasa maupun remaja (Tabel 8).

Tabel 8. Perubahan Histopatologi Hiperplasia dan Fusi pada Organ Insang Ikan Mujair yang Hidup di Alangkajeng Menak

\begin{tabular}{|c|c|c|c|c|c|c|c|c|}
\hline \multirow{3}{*}{$\overline{\text { Sampel }}$} & \multicolumn{8}{|c|}{ Perubahan Histopatologi } \\
\hline & & & & & & & & \\
\hline & $\mathrm{H}$ & $\mathrm{F}_{11}$ & D & $\mathrm{N}$ & $\mathrm{Fi}$ & مـ & $R$ & A \\
\hline |kamRememaja(AK-JO1) & 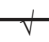 & $\nabla$ & $V$ & $\nabla$ & $\nabla$ & $\nabla$ & $r$ & \\
\hline Ikan Remaja (AK-J02) & $\sqrt{ }$ & $\sqrt{ }$ & $\sqrt{ }$ & $\sqrt{ }$ & $\sqrt{ }$ & $\sqrt{ }$ & $\sqrt{ }$ & $\sqrt{ }$ \\
\hline Ikan Remaja (AK-J03) & $\sqrt{ }$ & $\sqrt{ }$ & $\sqrt{ }$ & $\sqrt{ }$ & $\sqrt{ }$ & $\sqrt{ }$ & $\sqrt{ }$ & $\sqrt{ }$ \\
\hline Ikan Dewasa (AK-A01) & $\sqrt{ }$ & $\sqrt{ }$ & $\sqrt{ }$ & $\sqrt{ }$ & $\sqrt{ }$ & $\sqrt{ }$ & $\sqrt{ }$ & $\sqrt{ }$ \\
\hline Ikan Dewasa (AK-A02) & $\sqrt{ }$ & $\sqrt{ }$ & $\sqrt{ }$ & $\sqrt{ }$ & $\sqrt{ }$ & $\sqrt{ }$ & $\sqrt{ }$ & $\sqrt{ }$ \\
\hline Ikan Dewasa (AK-A03) & $\sqrt{ }$ & $\sqrt{ }$ & $\sqrt{ }$ & $\sqrt{ }$ & $\sqrt{ }$ & $\sqrt{ }$ & $\sqrt{ }$ & $\sqrt{ }$ \\
\hline
\end{tabular}

\section{Keterangan:}

$\mathrm{H}=$ Hiperplasia Fu $=$ Fusi $\mathrm{D}=$ Degenerasi $\mathrm{N}=$ Nekrosis

$\mathrm{Fi}=$ Fibrosis $\mathrm{O}=$ Oedema $\mathrm{R}=$ Radang $\mathrm{A}=$ Atropi

Pada pembacaan preparat organ insang ikan Mujair yang hidup di Dam Buagan diperoleh bahwa semua ikan baik ikan remaja maupun dewasa menunjukkan perubahan histopatologi hiperplasia dan fusi.Perubahan histopatologi degenerasi, nekrosis, fibrosis, eodema dan radang pada organ hati ditemukan pada semua sampel ikan Mujair baik ikan dewasa maupun ikan remaja yang hidup di Dam Buagan.Perubahan histopatologi pada organ otot yaitu atrofi ditemukan pada semua kategori umur ikan Mujair yang hidup di Dam Mertagangga (Tabel 9).

Tabel 9. Perubahan Histopatologi Hiperplasia dan Fusi pada Organ Insang Ikan Mujair yang Hidup di Dam Buagan

\begin{tabular}{|c|c|c|c|c|c|c|c|}
\hline \multirow{3}{*}{$\overline{\text { Sampel }}$} & \multicolumn{7}{|c|}{ Perubahan Histopatogin } \\
\hline & & & & & & & \\
\hline & H & Fll & D & $\mathrm{N}$ & $\mathrm{Fi}$ & مـ & $B \quad A$ \\
\hline \multicolumn{8}{|l|}{$\mathrm{HanRema(CM-101)}$} \\
\hline Ikan Remaja (GM-J02) & $\sqrt{ }$ & $\sqrt{ }$ & $\sqrt{ }$ & $\sqrt{ }$ & $\sqrt{ }$ & $\sqrt{ }$ & $\sqrt{ }$ \\
\hline Ikan Remaja (GM-J03) & $\sqrt{ }$ & $\sqrt{ }$ & $\sqrt{ }$ & $\sqrt{ }$ & $\sqrt{ }$ & $\sqrt{ }$ & $\sqrt{ } \quad \sqrt{ }$ \\
\hline Ikan Dewasa (GM-A01) & $\sqrt{ }$ & $\sqrt{ }$ & $\sqrt{ }$ & $\sqrt{ }$ & $\sqrt{ }$ & $\sqrt{ }$ & $\sqrt{ } \quad \sqrt{ }$ \\
\hline Ikan Dewasa (GM-A02) & $\sqrt{ }$ & $\sqrt{ }$ & $\sqrt{ }$ & $\sqrt{ }$ & $\sqrt{ }$ & $\sqrt{ }$ & $\sqrt{ }$ \\
\hline Ikan Dewasa (GM-A03) & $\sqrt{ }$ & $\sqrt{ }$ & $\sqrt{ }$ & $\sqrt{ }$ & $\sqrt{ }$ & $\sqrt{ }$ & $\sqrt{ }$ \\
\hline
\end{tabular}

\section{Keterangan:-}

$\mathrm{H}=$ Hiperplasia Fu $=$ Fusi $\mathrm{D}=$ Degenerasi $\mathrm{N}=$ Nekrosis

$\mathrm{Fi}=$ Fibrosis $\mathrm{O}=$ Oedema $\mathrm{R}=$ Radang $\mathrm{A}=$ Atropi

Pada ikan Mujair yang hidup di Dam Estuari ditemukan perubahan histopatologi organ insang berupa hiperplasia dan fusi pada semua kategori umur baik remaja maupun dewasa.Perubahan histopatologi yang terjadi pada organ hati ikan Mujair yang hidup di Dam Estuari yaitu degenerasi, nekrosis, fibrosis, oedema, dan radang ditemukan pada semua sampel ikan baik ikan dewasa maupun ikan remaja.Perubahan histopatologi atrofi pada otot ditemukan pada keseluruhan sampel ikan Mujair yang hidup di Dam Estuari baik ikan dewasa maupun remaja (Tabel 10).

Tabel 10. Perubahan Histopatologi Hiperplasia dan Fusi pada Organ Insang Ikan Mujair yang Hidup di Dam Estuari

\begin{tabular}{|c|c|c|c|c|c|c|c|c|}
\hline & & & & & 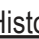 & & & \\
\hline Sampel & & & & & & & & \\
\hline & $\mathrm{H}$ & $F_{4}$ & D & $\mathrm{N}$ & $\mathrm{Fi}$ & مـ & $\mathrm{R}$ & $A$ \\
\hline HanRemaja(GM JO1) & 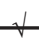 & لـ & & & & & & \\
\hline Ikan Remaja (GM-J02) & $\sqrt{ }$ & $\sqrt{ }$ & $\sqrt{ }$ & $\sqrt{ }$ & $\sqrt{ }$ & $\sqrt{ }$ & $\sqrt{ }$ & $\sqrt{ }$ \\
\hline Ikan Remaja (GM-J03) & $\sqrt{ }$ & $\sqrt{ }$ & $\sqrt{ }$ & $\sqrt{ }$ & $\sqrt{ }$ & $\sqrt{ }$ & $\sqrt{ }$ & $\sqrt{ }$ \\
\hline Ikan Dewasa (GM-A01) & $\sqrt{ }$ & $\sqrt{ }$ & $\sqrt{ }$ & $\sqrt{ }$ & $\sqrt{ }$ & $\sqrt{ }$ & $\sqrt{ }$ & $\sqrt{ }$ \\
\hline Ikan Dewasa (GM-A02) & $\sqrt{ }$ & $\sqrt{ }$ & $\sqrt{ }$ & $\sqrt{ }$ & $\sqrt{ }$ & $\sqrt{ }$ & $\sqrt{ }$ & $\sqrt{ }$ \\
\hline Ikan Dewasa (GM-A03) & $\sqrt{ }$ & $\sqrt{ }$ & $\sqrt{ }$ & $\sqrt{ }$ & $\sqrt{ }$ & $\sqrt{ }$ & $\sqrt{ }$ & $\sqrt{ }$ \\
\hline
\end{tabular}

\section{Keterangan: \\ $\mathrm{H}=$ Hiperplasia $\mathrm{Fu}=$ Fusi $\mathrm{D}=$ Degenerasi $\mathrm{N}=$ Nekrosis \\ $\mathrm{Fi}=$ Fibrosis $\mathrm{O}=$ Oedema $\mathrm{R}=$ Radang $\mathrm{A}=$ Atropi}

\section{PEMBAHASAN}

Kandungan logam berat timbal $(\mathrm{Pb})$ yang terkandung dalam tubuh ikan Mujair baik remaja maupun dewasa yang hidup pada aliran Tukad Badung di kota Denpasar melebihi ambang batas yang ditetapkan dalam SNI 7378:2009 yaitu sebesar $0,3 \mathrm{mg} / \mathrm{kg}$ (Gambar 1). Pada ikan Mujair yang hidup di Dam Estuari Suwung didapatkan kadar $\mathrm{Pb}$ tertinggi untuk kategori umur remaja maupun dewasa. Sedangkan untuk kandungan $\mathrm{Pb}$ terendah ditemukan pada ikan Mujair remaja dan dewasa yang hidup di Dam Mertagangga.Hal ini menunjukkan bahwa kandungan $\mathrm{Pb}$ di daerah hilir jauh lebih tinggi dibandingkan daerah hulu. Tingginya kandungan logam $\mathrm{Pb}$ didaerah hilir disebabkan oleh akumulasi limbah yang mengandung $\mathrm{Pb}$ yang dibawa oleh air dari hulu menuju hilir.

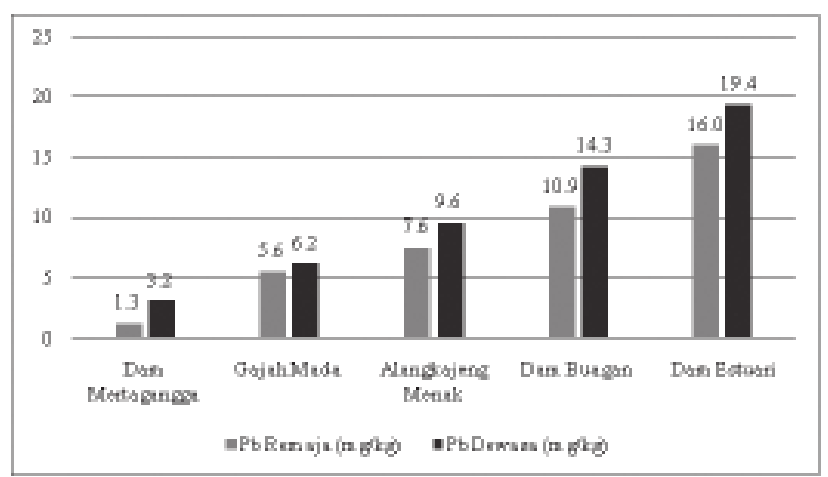

Gambar 1. Histogram Kandungan Rata-rata Logam Pb lkan Mujair yang Hidup di Tukad Badung Kota Denpasar

Menurut Palar (2002), timbal (Pb) adalah salah 
satu jenis logam berat berbahaya dan beracun. Logam ini banyak ditemukan sebagai bahan pencemar dan memiliki sifat cenderung mengganggu kelangsungan hidup organisme perairan.Logam ini masuk kedalam perairan melalui limbah buangan industri kimia, industri percetakan, industri yang menghasilkan logam dan cat (Yulaipi dan Aunurohim, 2013).

Pada ikan Mujair yang hidup di sepanjang aliran sungai Tukad Badung tidak ditemukan adanya kandungan logam berat kadmium (Cd). Sedangkan kandungan logam berat kromium $\left(\mathrm{Cr}^{+6}\right)$ yang terkandung dalam tubuh ikan Mujair baik remaja maupun dewasa yang hidup pada aliran Tukad Badung di kota Denpasar melebihi ambang batas yang ditetapkan oleh FAO dalam FAO Fish Circular 764 yaitu 1,0 mg/kg (Gambar 2).

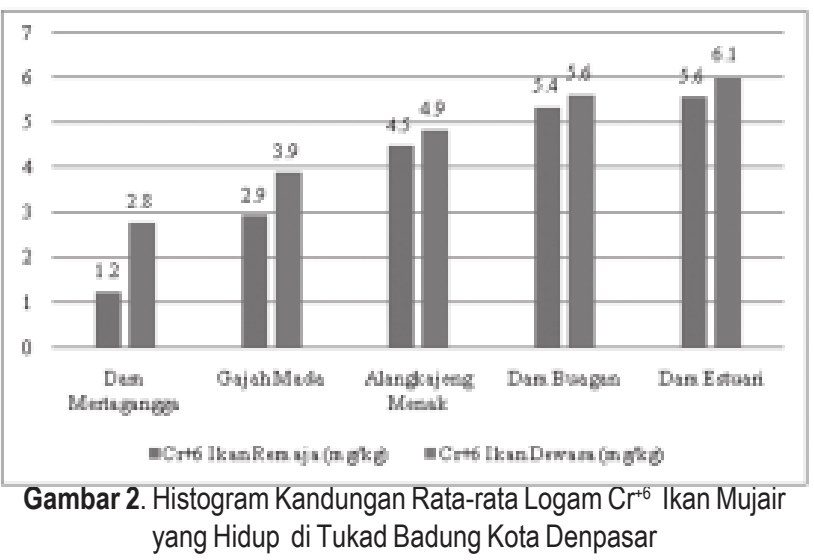

Pada ikan Mujair yang hidup di Dam Estuari Suwung diperoleh kadar $\mathrm{Cr}^{+6}$ tertinggi untuk kategori umur remaja maupun dewasa. Sedangkan untuk kandungan $\mathrm{Cr}^{+6}$ terendah ditemukan pada ikan Mujair remaja dan dewasa yang hidup di Dam Mertagangga. Menurut Widowati (2008), logam $\mathrm{Cr}^{+6}$ memiliki sifat toksik yang umum digunakan pada industri elektroplating, penyamakan kulit, cat tekstil, fotografi, pigmen (zat warna), besi baja serta industri kimia. Menurut data BLH Bali (2013), Sumber-sumber limbah mencemari sungai ini sangat beragam seperti limbah industri (industri pengolahan dan industri pencelupan), limbah rumah tangga, limbah bengkel, limbah limpasan jalan, limbah peternakan dan limbah rumah sakit, limbah pasar, dan lain sebagainya.

Akumulasi logam berat pada ikan terjadi akibat kontak antara medium yang mengandung logam berat dengan ikan. Kontak berlangsung dengan adanya proses pemindahan zat kimia dari lingkungan air ke dalam atau permukaan tubuh ikan. Masuknya logam berat kedalam tubuh ikan melalui tiga cara yaitu makanan, insang, dan difusi pada permukaan kulit (Sahetapi, 2011). Logam berat dapat terakumulasi dalam tubuh ikan dan tetap ada dalam jangka waktu yang lama sebagai racun. Logam teresebut dapat terdistribusi ke bagian tubuh manusia dan sebagian akan terakumulasi melalui berbagai perantara salah satunya makanan yang terkontaminasi logam berat (Sembiring, 2009). Logam berat yang masuk kedalam tubuh melalui insang akan mengalami ikatan dengan sel darah merah (eritrosit) dan beredar didalam plasma darah menuju seluruh organ dalam tubuh ikan diantaranya insang, daging, dan hati. Pada organ insang terjadi penurunan jumlah oksigen yang mampu diikat oleh sel darah merah sehingga mengakibatkan insang melakukan adaptasi dengan terus aktif bergerak untuk meningkatkan jumlah oksigen dalam darah yang berperan dalam proses metabolisme dalam tubuh ikan.

Menurut Landis, dkk. (2011), adanya logam berat dalam tubuh ikan akan menganggu sintesis haemoglobin $(\mathrm{Hb}), \mathrm{Hb}$ memiliki peran untuk mengikat oksigen, apabila sintesis $\mathrm{Hb}$ dihambat maka kemampuan utuk mengikat oksigen juga semakin kecil. Jika oksigen yang diikat sedikit maka akan mempengaruhi proses metabolisme. Enzim yang berperan aktif dalam sistesis Heme adalah ALAD dan Ferrochelatase.Purnomo (2007) menambahkan logam berat mengganggu sistem sintesis $\mathrm{Hb}$ dengan jalan menghambat konversi Delat Aminolevulinik asid-dehidratase (Delta-ALA) menjadi forbilinogen dan juga menghambat korporasi dari Fe kedalam protoporfirin IX untuk membentuk $\mathrm{Hb}$, dengan menghambat enzim delta-aminolevulinik asiddehidratase (delta-ALAD) dan feroketalase.Harteman (2011) menyebutkan logam berat terakumulasi dalam otot akibat sistem peredaran darah yang membawa sel darah merah yang berikatan dengan logam berat.Logam berat terakumulasi pada dinding pembuluh darah kapiler pada otot danjaringan ikat yang terdapat disekitar otot ikan.Sel darah merah yang telah berikatan dengan logam berat kemudian mengalir menuju hati.Hati merupakan organ yang berfungsi untuk mendetoksifikasi logam berat yang beredar didalam tubuh. Selain berikatan dengan sel darah merah, logam berat yang telah masuk kedalam tubuh dengan konsentrasi tinggi dapat menghambat aktivitas enzim melalui pembentukan senyawa antara logam berat dengan gugus sulfihidril (S-H) (Sahetapi, 2011). Enzim yang memiliki gugus S-H adalah kelompok enzim yang paling mudah mengalami gangguan. Hal ini dikarenakan gugus $\mathrm{S}-\mathrm{H}$ mudah berikatan dengan ion logam berat yang masuk kedalam tubuh, akibat dari adanya ikatan tersebut daya kerja enzim menjadi menurun bahkan sama sekali tidak bekerja (Palar, 2002). Menurut Landis, dkk. (2011), polutan yaitu logam berat akan bergabung dengan active site dari enzim sehingga akan menginaktifkan enzim tersebut. Logam berat akan berikatan kovalen dengan $\mathrm{S}$ pada gugus sulfihidril, yang mengakibatkan logam berat menginaktifkan enzim tersebut. Menurut Arain, dkk. (2008), kandungan logam berat pada ikan berbeda 
pada tiap bagiannya.Konsentrasi logam berat pada daging lebih rendah dibanding pada organ insang dan hati.Squadron (2012) menambahkan akumulasi logam berat pada daging lebih rendah dibanding insang, hal ini sesuai dengan peran fisiologi dalam metabolisme ikan dimana jaringan yang diserang oleh logam berat merupakan salah satu jaringan yang berperan aktif dalam metabolisme.Kandungan logam berat pada ikan Mujair yang hidup di Tukad Badung menunjukkan kondisi perairan Tukad Badung telah tercemar terutama oleh logam berat timbal dan kromium.Kandungan logam berat pada ikan bersifat akumulasi yang berarti kandungan logam berat pada tubuh ikan bertambah setiap waktunya tergantung lama paparan yang terlihat dari umur ikan tersebut.

Berdasarkan hasil pengamatan preparat organ dibawah mikroskop ditemukan bahwa terjadi perubahan histopatologi berupa hiperplasia sel klorid dan fusi pada lamella sekunder pada organ insang.Hal ini terjadi akibat adanya paparan logam berat pada kesemua sampel ikan yang dikoleksi di sepanjang aliran Tukad Badung (Gambar 3).Perubahan tersebut mulai ditemukan pada ikan Mujair remaja yang hidup di Dam Mertagangga dengan kandungan logam berat timbal sebesar $0,8385 \mathrm{mg} / \mathrm{kg}$ dan kromium heksavalen sebesar $1,1402 \mathrm{mg} / \mathrm{kg}$ pada dagingnya (Gambar 4). Ikan yangmulai menunjukkan perubahan histopatologi ini memiliki panjang badan $15,8 \mathrm{~cm}$, berat badan 157 gram, dengan perkiraan umur 2 bulan menunjukkan bahwa lama paparan logam berat terhadap ikan telah berlangsung selama 2 bulan. Perubahan ini juga teramati pada ikan mujair maupun dewasa pada lokasi lain yang memiliki kandungan logam berat lebih tinggi dibandingkan ikan Mujair yang hidup di Dam Mertagangga.

Hiperplasia sel klorid terjadi akibat polutan kimia dan logam berat (Olurin et al. 2006; Suparjo 2010). Tanjung (1982) mengelompokkan hiperplasia merupakan kerusakan insang yang berhubungan dengan bahan toksik sebagai kerusakan tingkat II dan III. Hiperplasia sel klorid mengakibatkan ruang interlamela yang merupakan saluran air tersumbat (Robert, 2001).Sel klorid berfungsi dalam transportasi ion dan detoksifikasi (Morrison, 2007). Peningkatan jumlah sel klorid akan mengurangi difusi gas dan dapat berakibat fatal seperti kematian, terganggunya difusi gas akibat luas permukaan serap pada lamella sekunder insang akan menyempit (Holle, et al. 2001).

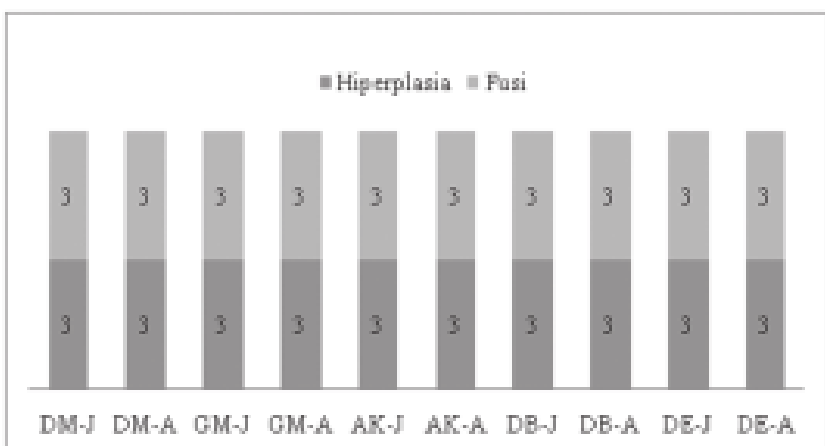

Gambar 3.Histogram Kejadian Perubahan Histopatologi Hiperplasia Sel Klorid dan Fusi pada Lamella Sekunder Organ Insang Ikan Mujair yang Hidup di Sungai Tukad Badung.

Keterangan :

DM-J : Ikan Remaja Dam Mertagangga

AK-A : Ikan Dewasa Alangkajeng Menak

DM-A : Ikan Dewasa Dam Mertagangga

DB-J : Ikan Remaja Dam Buagan

GM-J : Ikan Remaja Gajah Mada

DB-A : Ikan Dewasa Dam Buagan

GM-A : Ikan Dewasa Gajah Mada

DE-J : Ikan Remaja Dam Estuari

AK-J : Ikan Remaja Alangkajeng Menak

DE-A : Ikan Dewasa Dam Estuari

Hiperplasia sel klorid mengakibatkan fusi pada lamella sekunder. Ruang interlamela yang merupakan saluran air dan ruang produksi mucus dapat tersumbat akibat hiperplasia sel epitel yang berasal dari filament primer sehingga seluruh ruang intralamela diisi oleh sel-sel yang baru (Robert, 2001).

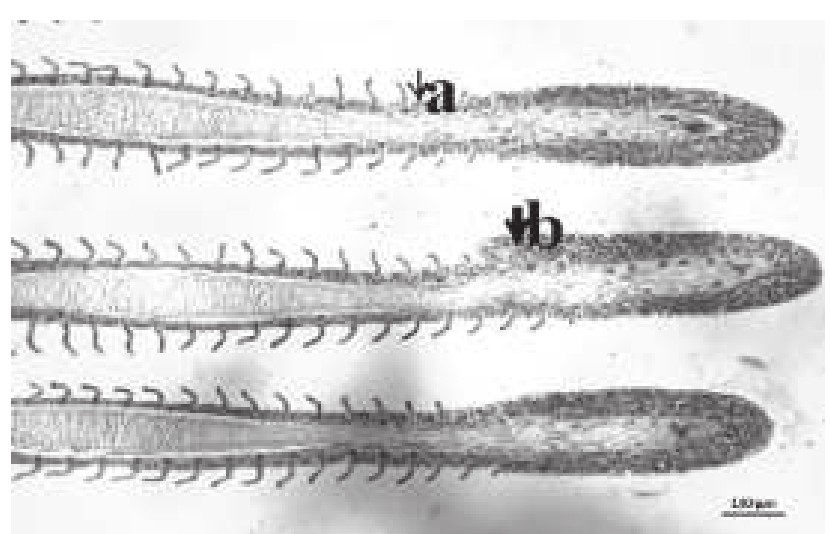

Gambar 4. Perubahan Histopatologi Hiperplasia Sel Klorid (a) dan Fusi Lamella Sekunder (b) Terjadi pada Ikan Mujair Remaja yang Hidup di Dam Mertagangga (HE, 100x)

Perubahan histopatologi organ hati berupa degenerasi, nekrosis, dan fibrosis terjadi pada seluruh sampel ikan Mujair yang diambil dari 
sepanjang aliran sungai Tukad Badung dan oedema beserta radang tidak ditemukan pada ikan Mujair baik remaja maupun dewasa yang hidup di Dam Mertagangga (Gambar 5).
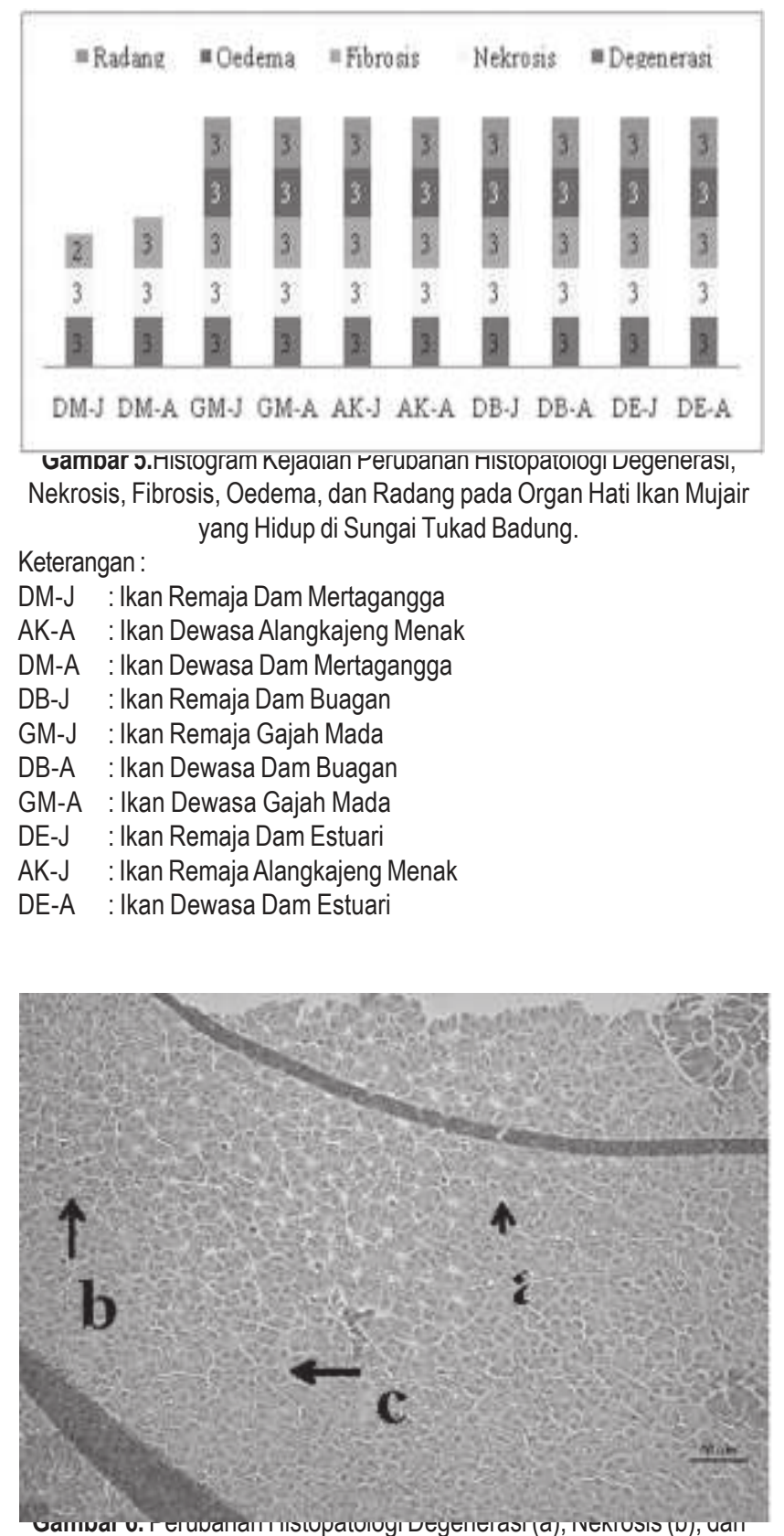

Fibrosis (c) Ditemukan pada Ikan Mujair Remaja yang Hidup di Dam Mertagangga(HE, 50x)

Dengan lama paparan 2 bulan, logam berat timbal dan kromium pada ikan Mujair remaja yang hidup di Dam Mertagangga dengan kandungan logam berat timbal $0,8385 \mathrm{mg} / \mathrm{kg}$ dan kromium $1,1402 \mathrm{mg} / \mathrm{kg}$ mampu mengakibatkan perubahan histopatologi degenerasi, nekrosis, dan fibrosis (Gambar 6). Perubahan histopatologi degenerasi, nekrosis, fibrosis, oedema, dan infiltrasi sel radang mulai ditemukan pada ikan remaja yang hidup di daerah jembatan Gajah Mada. Dengan kandungan logam berat timbal sebesar $4,5225 \mathrm{mg} / \mathrm{kg}$ dan kromium heksavalen sebesar 2,5163 mg/kg (Gambar 7).Perubahan histopatologi diatas terjadi akibat adanya zat beracun yang masuk kedalam tubuh ikan dari lingkungan. Ikan yang hidup di sungai Tukad Badung baik didaerah hulu maupun hilir mengalami kerusakan tingkat berat seperti yang diutarakan oleh Darmono (2005), bahwa kerusakan hati dibagi menjadi tiga yaitu ringan yang ditandai dengan perlemakan dan pembengkakan sel (oedema); sedang, ditandai dengan kongesti dan hemoragi; dan berat, ditandai dengan kematian sel atau nekrosis.

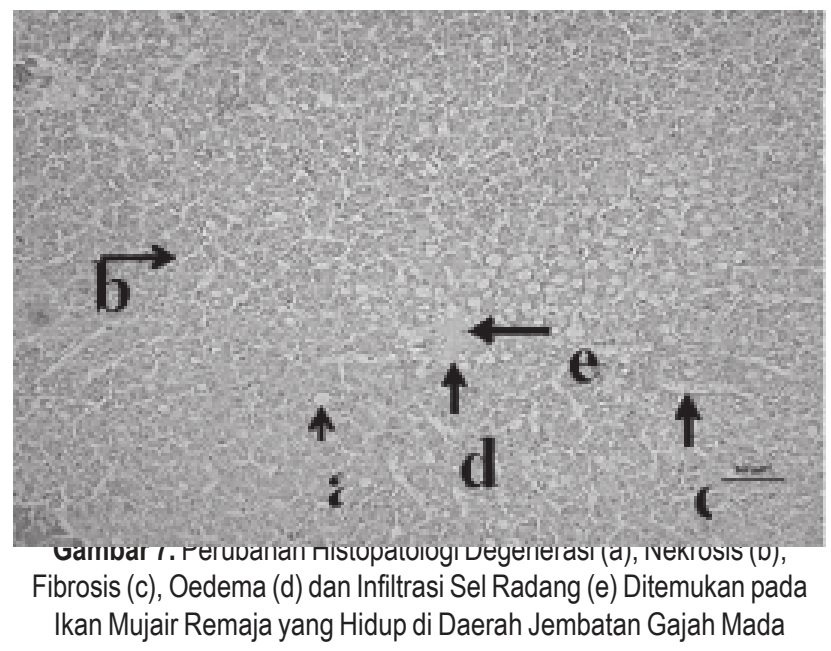
(HE, 50x)

Setyowati, dkk (2010) menyatakan adanya zat toksik dalam tubuh ikan dapat mempengaruhi stuktur histologi hati ikan.Ketidakstabilan sel dalam memompa ion $\mathrm{Na}$ + keluar dari sel menyebabkan meningkatnya cairan dari luar sel masuk kedalam sel sehingga sel tidak mampu memompa ion natrium yang cukup. Hal ini mengakibatkan sel mengalami pembengkakan dan kehilangan integritas membrane, sehingga sel akan mengeluarkan materi sel keluar dan kemudian terjadi kematian sel atau nekrosis. Adanya nekrosis menyebabkan respon peradangan pada jaringan yang masih hidup. Respon peradangan dilakukan dengan cara regenerasi selsel yang telah hilang, pembentukan jaringan ikat dan emigrasi leukosit kedaerah nekrosis. Apabila hati tetap terpapar zat toksik maka sel akan kehilangan kemampuan regenerasi dan menimbulkan terjadinya fibrosis. Anderson (1995), menambahkan fibrosis terjadi akibat peradangan akut karena sel kehilangan kemampuan regenerasi yang mengakibatkan terjadinya ploriferasi fibroblast. Jika fibrosis meluass keseluruh bagian hati maka akan terjadi serosis (pemadatan organ hati) yang menyebabkan kegagalan fungsi hati dan dapat mngakibatkan kematian (Setyowati, dkk. 2010).

Pada organ otot dari seluruh sampel ikan Mujair baik ikan remaja maupun dewasa yang hidup di aliran sungai Tukad Badung menunjukkan 
perubahan histopatologi atrofi (Gambar 8).Perubahan histopatologi atrofi mulai ditemukan pada preparat otot ikan Mujair remaja yang hidup di Dam Mertagangga yang memiliki kandungan logam berat timbal 0,8385 $\mathrm{mg} / \mathrm{kg}$ dan kromium 1,1402 mg/kg. Ikan Mujair remaja yang diambil dari Dam Mertagangga diperkirakan berumur 2 bulan, hal ini menunjukkan bahwa dengan kandungan logam berat timbal dan kromium tersebut diatas mampu mengakibatkan perubahan histopatologi otot berupa atropi.Plumb (1994) menyatakan atrofi pada otot karena kurangnya suplai nutrisi dan suplai darah. Adanya paparan logam berat pada tubuh ikan mengakibatkan ikan kesulitan menangkap oksigen dari lingkungan akibat kerusakan pada insang ikan yang berfungsi sebagai organ pernafasan. Hal ini akan berdampak pada proses sirkulasi dalam tubuh ikan, salah satunya sel darah merah yang bertugas membawa asupan nutrisi dan oksigen ke dalam otot mengalami penurunan jumlah.

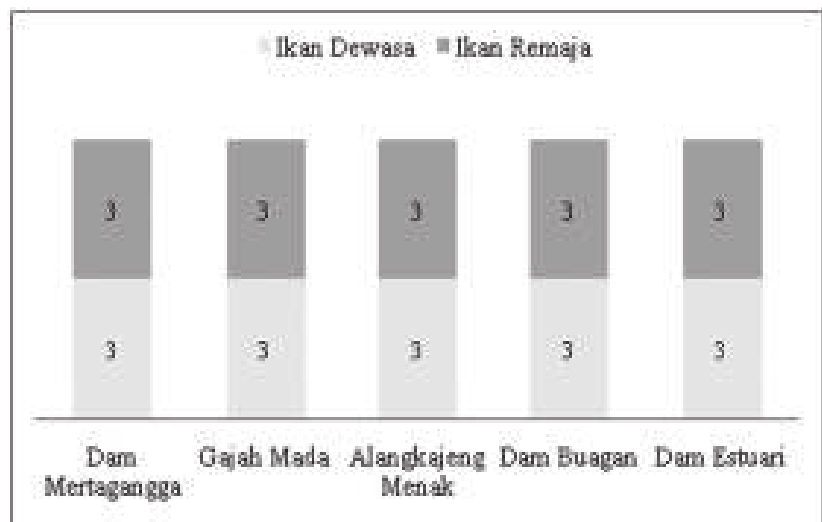

Gambar ४. HIstogram Kejadıan Herupanan HIstopatologı Atrotı pada Organ Otot lkan Mujair yang Hidup di Sungai Tukad Badung.

Sel-sel otot akan mengalami atrofi atau penurunan ukuran sel maupun penurunan jumlah sel. Atrofi berlangsung secara perlahan dan mengakibatkan abnormalitas ukuran tubuh ikan (Plumb, 1994). Atrofi sel otot dapat dilihat dari jarak antara myoseptum dengan myomer menjadi berjauhan, dimana pada keadaan normal myoseptum dan myomer saling berdekatan (Gambar 9). Perubahan histopatologi yang terjadi menunjukkan pengaruh besar logam berat terhadap susunan sel dari tubuh ikan Mujair yang hidup di Tukad Badung.Paparan logam berat mengakibatkan gangguan fisiologis pada tubuh ikan yang mengakibatkan tubuh ikan beradaptasi terhadap paparan logam berat tersebut. Perubahan histologi paling awal akan dialami oleh organ insang karena insang merupakan organ yang paling sering kontak dengan akibat logam sebagaimana fungsi organ insang sebagai organ pernafasan dengan mengambil oksigen dari lingkungan dan melepaskan karbondioksida.

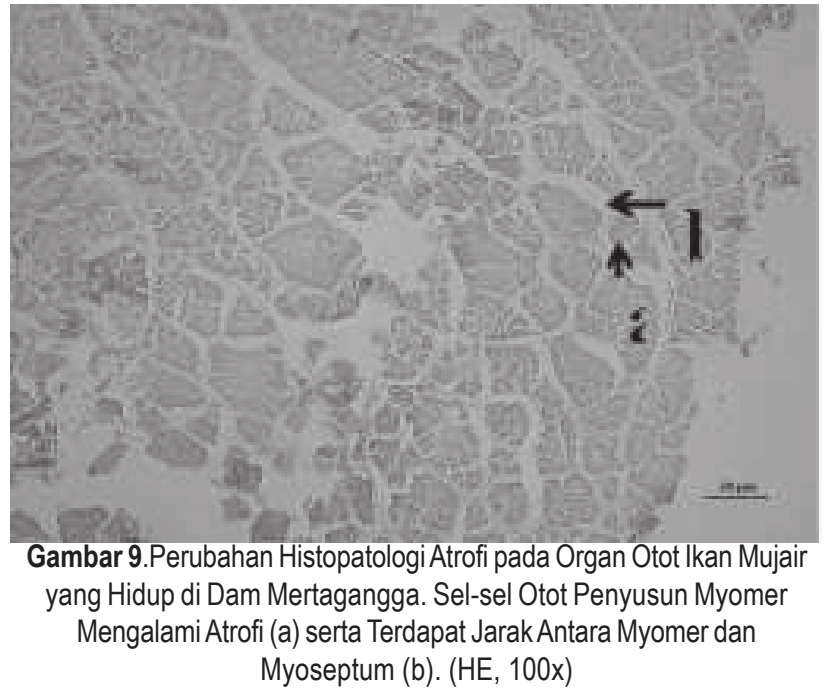

Sel darah merah yang berikatan dengan logam berat akan beredar ke seluruh tubuh. Logam berat yang tergolong bahan beracun akan didetoksifikasi oleh hati. Bahan beracun dalam tubuh ikan mengganggu proses transfer elektron pada sel hati sehingga mengakibatkan adanya perubahan histopatologi sel hati yang berdampak ikan akan mengalami keracunan dan kematian akibat ketidakmampuan hati untuk mendetoksifikasi racun yang beredar dalam tubuh. Sel darah merah dengan logam berat yang seharusnya membawa oksigen untuk metabolisme dalam tubuh ikan mengakibatkan organ-organ dalam tubuh ikan termasuk otot mengalami malnutrisi sehingga terjadi penurunan kondisi fisiologis dan diiringi perubahan histopatologi yaitu sel otot akan mengalami pengecilan dan penurunan jumlah akibat ketidak mampuan sel darah menyediakan nutrisi bagi otot.

\section{SIMPULAN DAN SARAN}

Biokonsentrasi cemaran logam berat pada ikan Mujair (Oreochromis mossambicus) yang hidup diperairan sungai Tukad Badung melebihi baku mutu SNI 7378:2009 yaitu 0,3 mg/kg untuk logam timbal dan FAO Fish Circular 764 yaitu $1 \mathrm{mg} / \mathrm{kg}$ untuk logam kromium heksavalen serta tidak ditemukan kandungan logam berat kadmium $(\mathrm{Cd})$ pada ikan Mujair (Oreochromis mossambicus) yang hidup diperairan sungai Tukad Badung. Pada biokonsentrasi logam berat timbal $(\mathrm{Pb}) 0,8385 \mathrm{mg} /$ $\mathrm{kg}$ dan kromium heksavalen sebesar 1,1402 mg/kg pada ikan Mujair (Oreochromis mossambicus) yang hidup diperairan sungai Tukad Badung ditemukan perubahan histopatologi hiperplasia dan fusi pada insang, degenerasi, nekrosis, dan fibrosis pada hati dan atropi pada otot. Sedangkan perubahan histopatologi oedema dan nekrosis pada hati ditemukan pada ikan dengan biokonsentrasi logam berat timbal sebesar $4,5225 \mathrm{mg} / \mathrm{kg}$ dan kromium 
heksavalen sebesar 2,5163 mg/kg.Ikan Mujair yang hidup di perairan Tukad Badung tidak layak untuk dikonsumsi karena memiliki kandungan logam berat melebihi baku mutu yang berlaku sehingga perlu diambil kebijakan tentang pengelolaan lingkungan perairan Tukad Badung dan perlu diadakan penelitian komprehensif tentang biokonsentrasi berbagai logam berat terhadap biota yang hidup di perairan Tukad Badung dihubungkan dengan logam berat pada sedimen sepanjang aliran di perairan Tukad Badung.

\section{DAFTAR PUSTAKA}

Anderson, P.S. 1995. Patofisiologi Konsep Klinis Proses-proses Penyakit. Alih Bahasa : Peter Anugrah. EGC Penerbit Buku Kedokteran : Jakarta.

Arain, MB., T.G. Kazi, M.K. Jamali, N. Jalbani, H.I, Alfridi, A. Shah. 2008. Total Disolved and Bioavailable Element in Water and Sediment Samples and Their Accumulation in Oreochromis mossambicus of Polluted Manchar Lake. Chemsphere 70 (2008) 1845-1856.

BLH Bali. 2013. Laporan Akhir Pekerjaan Analisis Data Kualitas Air. Badan Lingkungan Hidup Provinsi Bali

BSN. 2009. Batas Maksimum Cemaran Logam Berat dalam Pangan SNI 7387. Badan Standarisasi Nasional Republik Indonesia. Jakarta.

Cahaya, Indra. 2009. Ikan Sebagai Alat Monitor Kesehatan. Makalah Bagian Kesehatan Lingkungan, Fakultas Kesehatan Masyarakat, Universitas Sumatera Utara.

Dutta, H.M., dan J.S.D Munshi. 1996. Fish Morphology, Horrizon of New Research Science Publisher, Inc. USA.

FAO. 1983. Compilation of Legal Limits for Hazardous Substances in Fish and Fishery Products. Fisheries Circular No. 764. Food Agricultural Organization. Rome.

Goenarso, D. 1988. Perubahan Faal Ikan Sebagai Indikator Kehadiran Insektisida dan Detergen Dalam Air. Disertasi. ITB. Bandung.

Harteman, E. 2011. Dampak Kandungan Logam Berat terhadap Kemunculan Polimorfisme Ikan Badukang (Arius maculates Fis\&Bian) dan Sembilang (Plotosus canius Web\&Bia) di Muara Sungai Kahayan serta Katingan, Kalimantan Tengah. ITB. Bogor.

Hoole, D., D. Bucke, P. Burgess dan I. Wellby. 2001. Disease of Carp and Other Cyprinid Fishes. Blackwell Science Ltd: United Kingdom.

Landis, Wayne G., R. M. Solfield, Ming-Hoyu. 2011. Introduction To Environmental Toxicology Molecular Substructure to Ecological Landscapes $4^{\text {th }}$ Edition. CRC Press Taylor \& Franciss Group. Marrison, John. 2007. Normal Histology. In :
Momford, S., J. Heidel, C. Smith, J. Marrison, B. MacConnel dan V. Blazer. Fish Histology and Histopathology.

Mason, Christhoper. 2002. Biology Of Freshwater Pollution. Fourth Edition. Prentice Hall. England.

Olurin, K.B., A.A. Olojo, G.O.Mbaka dan A.T. Akindele. 2006. Histopatological Responses of the Gill and Liver Tissues of Clarias gariepinus Fingerlings to the Herbicide, Glyphosate. African Journal of Biotechnology, hal 2480-2487.

Palar, H. 2002. Pencemaran dan Toksikologi Logam Berat. Rineka Cipta: Jakarta

Plumb, J.A. 1994. Health Maintenance of Cultured Fish: Principal Microbial Fish. CRC Press Inc. USA.

Purnomo, T., Muchyiddin. 2008. Analisa Kandungan Timbal ( $\mathrm{Pb}$ ) pada Ikan Bandeng (Chanos chanos) di Tambak Kecamatan Gresik. Neptunus vol 14 No 1: 69-77.

Robert R. J. 2001. Fish Pathology. Edisi ketiga. W.B. Saunders. London.

Sahetapi, J. M. 2011. Toksisitas Logam Berat Timbal (Pb) dan Pengaruhnya pada Konsumsi Oksigen dan Respon Hematologi Juvenil Ikan Kerapu Macan. Thesis. Pasca Sarjana IPB, Bogor.

Sembiring, R. 2009. Analisis Kandungan Logam Berat $\mathrm{Hg}, \mathrm{Cd}$, dan $\mathrm{Pb}$ pada Daging Kijing Lokal (Pilsbryoconcha exilis) dari Perairan Situgede, Bogor. Skripsi. Departemen Teknologi Perairan FPIK. ITB.

Setyowati, A., D. Hidayati, Awik, P.D.N, dan N. Abdulgani. 2010. Studi Histopatologi Hati Ikan Belanak (Mugil cephalus) di Muara Sungi Aloo Sidoarjo. Skripsi. ITS. Surabaya.

Squadron, S., M. Prearo, P. Bizio, S. Gavinelli, M. Pellegrino, T. Scanzio, S. Guarise, A. Benedetto, M.C. Abece. 2012. Heavy Metals Distribution in Muscle, Liver, Kidney, an Gill of European Catfish (Silurus glanis) from Italian Rivers. Chemophere xxx.

Suparjo, M. N. 2010. Kerusakan Jaringan Insang Ikan Nila (Oreochromis niloticus) Akibat Deterjen. Jurusan Saintek Perikanan 5 (2) hal 1-7.

Tanjung, S. 1982. The Toxicity of Aluminium for Organs of Salvalinus Fontanalis Mitchill in Acid Water. Jakarta

Widowati, W. 2008. Efek Toksik Logam. Penerbit Andi: Yogyakarta.

Yulaipi, S. dan Aunurohim. 2013. Bioakumulasi Logam Berat Timbal $(\mathrm{Pb})$ dan Hubungannya dengan Laju Pertumbuhan Ikan Mujair (Oreochromis mossambicus). Jurnal Sains dan Seni PomitsVol. 2 No. 2. Hal 166-170. 